\title{
Sociodemographic Factors of Alcohol Consumption in a Population of Hospitalized Patients in Ouagadougou (Burkina Faso)
}

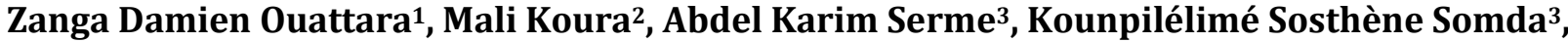 Aboubacar Coulibaly ${ }^{3}$, Steve Léonce Zoungrana ${ }^{1}$, Appolinaire Sawadogo ${ }^{2}$}

\author{
${ }^{2}$ Hepato-Gastroenterology Unit CHU-SS, Bobo Dioulasso, Burkina Faso \\ ${ }^{3}$ Hepato-Gastroenterology Unit CHU-YO, Ouagadougou, Burkina Faso \\ Email: damzang@yahoo.com
}

${ }^{1}$ Hepato-Gastroenterology Unit CHU Ouahigouya, UFR/SDS CUP, Ouahigouya, Burkina Faso

How to cite this paper: Ouattara, Z.D., Koura, M., Serme, A.K., Somda, K.S., Coulibaly, A., Zoungrana, S.L. and Sawadogo, A. (2017) Sociodemographic Factors of Alcohol Consumption in a Population of Hospitalized Patients in Ouagadougou (Burkina Faso). Open Journal of Gastroenterology, 7, 96-104.

https://doi.org/10.4236/ojgas.2017.73011

Received: January 20, 2017

Accepted: March 26, 2017

Published: March 29, 2017

Copyright (c) 2017 by authors and Scientific Research Publishing Inc. This work is licensed under the Creative Commons Attribution International License (CC BY 4.0).

http://creativecommons.org/licenses/by/4.0/

\begin{abstract}
The prevalence of excessive alcohol consumption is high in our context. The fight against this scourge requires accurate identification of sociodemographic factors for a better communication strategy. Objective: To determine the sociodemographic factors associated with alcohol consumption in a population of hospitalized patients. Methods: A cross-sectional study was conducted during two months in 14 hospital departments of the University Hospital CHU-Yalgado Ouédraogo (CHUYO) in Ouagadougou, by interview and document review. All patients hospitalized for less than a year, aged 18 at least and consenting were included. Excessive alcohol consumption was defined as consumption $\geq 210 \mathrm{~g} /$ week in men and $140 \mathrm{~g} /$ week in women according to WHO, a score $\geq 8$ in men and in women $\geq 7$ by AUDIT Questionnaire, a score $\geq 2$ according to the DETA questionnaire. Socio-demographic factors as age, sex, religion, educational level, marital status, occupation and salary status were filled for all patients. Results: A total of 391 patients were included. The average age was $44 \pm 16.26$ years and the sex ratio of 1.34 . Among them, 135 (34.53\%) were consumers of alcohol. The prevalence of excessive consumption ranged from $7.92 \%$ to $10.49 \%$. A statistically significant relationship was found between alcohol consumption and sex $(\mathrm{p}<0.03)$, religion $(\mathrm{p}<0.01)$ and education level $(\mathrm{p}<0.01)$. On the contrary, no significant relationship was found between alcohol consumption, age, marital status and occupation. The salary status "employee" appears to promote the consumption of alcohol by some tools. Conclusion: The excessive consumption of alcohol is common in our population especially by educated men of non-Muslim religion. This hypothesis should be corroborated in a study within the general population to better set control strategies against this scourge.
\end{abstract}




\section{Keywords}

Alcohol, Sociodemographic Factors

\section{Introduction}

Drinking alcohol is an integral part of the customs of African people. Alcohol plays several roles and functions both in the socialization of people and in customary rites and beliefs.

However, excessive consumption of alcohol is a proven risk factor for cardiovascular diseases and cancers. As such, its sociodemographic characteristics should be specified, especially in a rapidly changing African society with an increasingly westernized lifestyle. Alcohol imported into developing countries, particularly in black Africa, has followed the roads and paths to reach even the most remote villages, where its consumption added to artisanal and traditional alcoholic beverages [1].

Few studies in Africa focus on the topic of alcohol-drinking patients. The rare studies often restrict to data on prevalence in specific groups such as pupils, students and other teenagers and not on factors that could be related to excessive consumption [2] [3] [4].

In the first part of this study comparing the consumption of alcoholic evaluation methods in a population of hospitalized patients in Ouagadougou, we determined the prevalence of patients who over drink.

The objective of the second part was to determine the sociodemographic factors associated with excessive alcohol consumption in this population of patients hospitalized in Ouagadougou in order to contribute to improve population awareness strategy.

\section{Patients and Methods}

The framework of our study was the University Hospital Yalgado Ouedraogo of Ouagadougou (CHU-YO). This is the first referral center at the national level. We performed a cross-sectional study conducted during the months of April and May 2014 in 14 hospital wards, except pediatric, psychiatric, emergency wards and intensive care. All patients hospitalized for less than a year, aged 18 at least and consenting were included in the study. The exclusion criteria were: patients in poor general condition, or aphasia, or hospitalized in the delivery room.

The protocol was approved by the hospital ethics committee of CHUYO.

Data were collected by a physician in fourth year of specialized training in hepatogastroenterology by interview and document review (medical records), with individual collection sheet. Socio-demographic data of patients were collected: gender, age, occupation, educational level, marital status, religion, and salary status. The data were processed using the Epi Info 7 software.

To determine excessive alcohol consumption, we used the WHO standards 
according to which, alcohol consumption is excessive when it is greater than or equal to $210 \mathrm{~g}$ per week (or 21 glasses) in men and $140 \mathrm{~g}$ (14 glasses) in women [5] [6].

For the AUDIT questionnaire, a score $\geq 8$ in men and in women $\geq 7$ was selected as evocative of an alcohol misuse. A score $>12$ in men and $>11$ in women is in favor of alcohol dependence [7].

For DETA questionnaire, a score $\geq 2$ was used to define excessive alcohol consumption [8].

For analyzes, several tests were used: the comparison of percentages was made by chi-square test or the Fisher exact test based on the number; comparison of means was made by ANOVA test or t-test; Pearson's correlation coefficient was used to establish links between the continuous quantitative variables. The confidence interval was set at $95 \%$. A test was considered significant for $\mathrm{p}$ less than 0.05 .

\section{Results}

Out of 1786 patients hospitalized during the study period, 391 meeting inclusion criteria were included in the study. There were 224 men (57.3\%) and 167 women $(42.7 \%)$ or a sex ratio of 1.34 . The mean age was $16.3 \pm 44.1$ years (Table 1 ). There were 135 alcohol consumers or $34.5 \%$. Males accounted for $72.5 \%$ of drinkers with a risk ratio $(R R)$ of $1.47(\mathrm{p}<0.01)$.

According to WHO standards, 31 patients (7.92\%) had excessive alcohol consumption including 8 women (4.79\%) and 23 men (10.27\%). According to the AUDIT questionnaire, 41 in-patients (10.49\%) had inappropriate alcohol use (misuse plus dependence); while for DETA Questionnaire 32 (8.2\%) had a harmful drinking (Table 2).

We observed a statistical link between excessive alcohol consumption and male sex (RR: 1.32 to $1.54 \mathrm{p}<0.03$ ) (Table 2), religion ( $<0.01$ ) (Table 3 ) education level ( $\mathrm{p}<0.01)$ (Table 4, Table 5). We did not observe significant association between alcohol consumption and age $(r=0.1)$, occupation, and marital status. For the "employee" status, results are ambiguous and depend on the tools used (p: $0.0010-0.0058$ ) (Table 6).

\section{Discussion}

Among the hospitalized patients of CHUYO of Ouagadougou, $34.53 \%$ were drinkers. The prevalence of excessive consumption ranged from $7.92 \%$ to $10.49 \%$ and men consume more alcohol than women.

Some limitations of the study should be emphasized: the non-inclusion of certain departments (psychiatry, medical emergencies, traumatology and visceral emergencies) that receive cases of acute alcohol and alcohol "weaning" syndrome does not document the socio-demographic profile of these patients. Furthermore answering a questionnaire could lead to sociologically acceptable answers. 
Table 1. General characteristics of hospitalized respondents about their alcohol consumption CHUYO Ouagadougou, March-April, 2014.

\begin{tabular}{|c|c|c|c|}
\hline Characteristics & Women (\%) & Men (\%) & Total (\%) \\
\hline \multicolumn{4}{|l|}{ Age range (year) } \\
\hline $10-19$ & $6(54.55)$ & $5(45.45)$ & $11(2.81)$ \\
\hline $20-29$ & $38(52.05)$ & $35(47.95)$ & $73(18.67)$ \\
\hline $30-39$ & $37(44.58)$ & $46(55.42)$ & $83(21.23)$ \\
\hline $40-49$ & $35(43.21)$ & $46(56.79)$ & $81(20.72)$ \\
\hline $50-59$ & $21(32.31)$ & $44(67.69)$ & $65(16.62)$ \\
\hline $60-69$ & $17(38.64)$ & $27(61.36)$ & $44(11.25)$ \\
\hline $70-79$ & $13(44.83)$ & $16(55.17)$ & $29(7.42)$ \\
\hline $80-89$ & 0 & $5(100)$ & $5(1.28)$ \\
\hline \multicolumn{4}{|l|}{ Education level } \\
\hline Uneducated & $114(51.35)$ & $108(48.65)$ & $222(56.78)$ \\
\hline Primary & $26(34.67)$ & $49(65.33)$ & 75 (19.18) \\
\hline Secondary & $21(31.34)$ & $46(68.66)$ & $67(17.14)$ \\
\hline \multirow[t]{2}{*}{ University } & $6(22.22)$ & $21(77.78)$ & $27(6.91)$ \\
\hline & 167 & 224 & 391 \\
\hline \multicolumn{4}{|l|}{ Profession } \\
\hline Farmer/breeder & $41(33.88)$ & $80(66.12)$ & $121(30.95)$ \\
\hline Informal sector & $25(30.12)$ & $58(69.88)$ & $83(21.23)$ \\
\hline FAF/Housewives & $74(100)$ & 0 & $74(18.93)$ \\
\hline Liberal profession & $8(18.18)$ & $36(81.82)$ & $44(11.25)$ \\
\hline Civil servants & $11(33.33)$ & $22(66.67)$ & $33(8.44)$ \\
\hline Retired & $1(5.88)$ & $16(94.12)$ & $17(4.35)$ \\
\hline Pupils/Students & $6(46.15)$ & $7(53.85)$ & $13(3.32)$ \\
\hline \multirow[t]{2}{*}{ Jobless } & $1(16.67 \%)$ & $5(83.33)$ & $6(1.53)$ \\
\hline & 167 & 224 & 391 \\
\hline \multicolumn{4}{|l|}{ Religion } \\
\hline Muslim & $94(41.78)$ & $131(58.22)$ & $225(57.54)$ \\
\hline Catholic & $53(41.41)$ & 75 (58.59) & $128(32.74)$ \\
\hline Protestant & $18(56.25)$ & $14(43.75)$ & $32(8.18)$ \\
\hline Traditional & $1(20)$ & $4(80)$ & $5(1.28)$ \\
\hline \multirow[t]{2}{*}{ Without religion } & $1(100)$ & $0(0)$ & $1(0.26)$ \\
\hline & 167 & 224 & 391 \\
\hline \multicolumn{4}{|l|}{ Matrimonial status } \\
\hline Married & $140(43.34)$ & $183(56.66)$ & $323(82.61)$ \\
\hline Single & $22(39.92)$ & $41(65.08)$ & $63(16.11)$ \\
\hline Widower/widow & $5(100)$ & $0(0)$ & $5(1.28)$ \\
\hline \multicolumn{4}{|l|}{ Salary status } \\
\hline No & $148(47.74)$ & $162(52.26)$ & $310(79.28)$ \\
\hline Yes & $19(23.46)$ & $62(76.54)$ & $82(20.72)$ \\
\hline
\end{tabular}


Table 2. Comparison by sex of the results of alcohol screening questionnaires in hospitalized patients of CHUYO of Ouagadougou, March-April 2014.

\begin{tabular}{ccccc}
\hline & \multicolumn{4}{c}{ SEXE } \\
\cline { 2 - 4 } GROUP OF CONSUMER & $\mathrm{M}$ & $\mathrm{F}$ & TOTAL & \\
\cline { 2 - 4 } GROUP_WHO_POSITIVE & 23 & 8 & 31 & $\mathrm{RR}=1.32 ;$ \\
GROUP_WHO_NEGATIVE & 201 & 159 & 360 & $\begin{array}{c}\text { X2 }=3.21 ; \\
\mathrm{p}=0.023\end{array}$ \\
TOTAL & 224 & 167 & 391 & \\
\hline AUDIT (+) & 35 & 6 & 41 & $\mathrm{RR}=1.5 ;$ \\
AUDIT (-) & 198 & 161 & 350 & $\mathrm{X} 2=12.59$ \\
TOTAL & 224 & 167 & 391 & $\mathrm{p}=0.00005$ \\
\hline DETA (+) & 27 & 5 & 32 & $\mathrm{RR}=1.53$ \\
DETA (-) & 197 & 162 & 350 & $\mathrm{X} 2=9.27 ;$ \\
TOTAL & 24 & 167 & 391 & $\mathrm{p}=0.0004$ \\
\hline
\end{tabular}

Table 3. Comparison and Inter religious groups as defined by the diagnostic tools.

\begin{tabular}{cccc}
\hline & WHO Group & AUDIT Group & DETA Group \\
\hline Catholic-Muslim & $\mathrm{p}=0.0000005$ & $\mathrm{p}=0.00000000019$ & $\mathrm{p}=0.000000005$ \\
& $\mathrm{RR}=2.57$ & $\mathrm{RR}=2.66$ & $\mathrm{RR}=2.57$ \\
& & & \\
Catholic-Protestant & $\mathrm{p}=0.4(\mathrm{NS})$ & $\mathrm{p}=0.15(\mathrm{NS})$ & $\mathrm{p}=0.47$ (NS) \\
& $\mathrm{RR}=1.05$ & $\mathrm{RR}=1.12$ & $\mathrm{RR}=1.01$ \\
& & & \\
Catholic-Traditional & $\mathrm{p}=0.2(\mathrm{NS})$ & $\mathrm{p}=0.33(\mathrm{NS})$ & $\mathrm{p}=0.2(\mathrm{NS})$ \\
& $\mathrm{RR}=0.93$ & $\mathrm{RR}=0.96$ & $\mathrm{RR}=0.93$ \\
& & & $\mathrm{p}=0.001$ \\
Muslim-Protestant & $\mathrm{p}=0.005$ & $\mathrm{p}=0.02$ & $\mathrm{RR}=0.49$ \\
& $\mathrm{RR}=0.56$ & $\mathrm{RR}=0.67$ & $\mathrm{p}=0.0054$ \\
& & $\mathrm{p}$ & $\mathrm{RR}=0.67$ \\
Muslim-Traditional & $\mathrm{p}=0.005$ & $\mathrm{p}=0.01$ & $\mathrm{p}=0.23$ \\
& $\mathrm{RR}=0.67$ & $\mathrm{RR}=0.76$ & $\mathrm{RR}=0.79$ \\
\hline
\end{tabular}

Table 4. Distribution of average grams of alcohol per week depending on the level of education.

\begin{tabular}{cccc}
\hline Education level & Numbers & Average & \\
\hline Uneducated & 222 & $25.58 \pm 81.36$ & \\
Primary & 75 & $56.45 \pm 124.87$ & $\begin{array}{c}\text { Anova test } \\
\mathrm{Df}=3\end{array}$ \\
Secondary & 67 & $39.35 \pm 72.54$ & $\mathrm{p}<0.00002$ \\
University & 27 & $117.36 \pm 140.63$ & \\
\hline
\end{tabular}


Table 5. Distribution of alcohol consumption in grams/week according to the education level and groups determined by the tools.

\begin{tabular}{|c|c|c|c|c|}
\hline & Education level & Number & Average in grams per week & \\
\hline \multirow{4}{*}{$\begin{array}{l}\text { WHO group } \\
\text { Negative }\end{array}$} & Unschooled & 210 & $10.47 \pm 31.09$ & \multirow{4}{*}{$\begin{array}{l}\text { Anova test. } \\
\quad \mathrm{df}=3 \\
\mathrm{p}=0.0018\end{array}$} \\
\hline & Primary & 67 & $24.83 \pm 47.15$ & \\
\hline & Secondary & 63 & $26.10 \pm 50.75$ & \\
\hline & University & 20 & $49.20 \pm 68.83$ & \\
\hline \multirow{4}{*}{$\begin{array}{l}\text { WHO Group } \\
\text { Positive }\end{array}$} & Unschooled & 12 & $295.13 \pm 176.17$ & \multirow{4}{*}{$\begin{array}{c}\text { Anova test. } \\
\quad \mathrm{df}=3 \\
\mathrm{p}=0.91(\mathrm{NS})\end{array}$} \\
\hline & Primary & 8 & $321.29 \pm 232.68$ & \\
\hline & Secondary & 4 & $248.05 \pm 27.75$ & \\
\hline & University & 7 & $312.12 \pm 68.83$ & \\
\hline \multirow{4}{*}{$\begin{array}{c}\text { AUDIT Group } \\
\text { Negative }\end{array}$} & Unschooled & 206 & $7.72 \pm 23.81$ & \multirow{4}{*}{$\begin{array}{l}\text { Anova test. } \\
\quad \mathrm{df}=3 \\
\mathrm{p}=0.00000\end{array}$} \\
\hline & Primary & 63 & $18.52 \pm 38.98$ & \\
\hline & Secondary & 60 & $21.76 \pm 47.36$ & \\
\hline & University & 21 & $59.18 \pm 80.11$ & \\
\hline \multirow{4}{*}{$\begin{array}{l}\text { AUDIT Group } \\
\text { Positive }\end{array}$} & Unschooled & 16 & $259.43 \pm 164.58$ & \multirow{4}{*}{$\begin{array}{c}\text { Anova test. } \\
\quad \mathrm{df}=3 \\
\mathrm{p}=0.55(\mathrm{NS})\end{array}$} \\
\hline & Primary & 12 & $255.58 \pm 211.74$ & \\
\hline & Secondary & 7 & $190.10 \pm 78.85$ & \\
\hline & University & 6 & $320.99 \pm 114.89$ & \\
\hline \multirow{4}{*}{$\begin{array}{c}\text { DETA Group } \\
\text { Negative }\end{array}$} & Unschooled & 210 & $11.55 \pm 34.87$ & \multirow{4}{*}{$\begin{array}{c}\text { Anova test. } \\
\mathrm{df}=3 \\
\mathrm{p}=0.00000\end{array}$} \\
\hline & Primary & 65 & $25.78 \pm 54.89$ & \\
\hline & Secondary & 61 & $27.43 \pm 62.11$ & \\
\hline & University & 23 & $90.12 \pm 123.87$ & \\
\hline \multirow{4}{*}{$\begin{array}{l}\text { DETA Group } \\
\text { Positive }\end{array}$} & Unschooled & 12 & $276.26 \pm 193.92$ & \multirow{4}{*}{$\begin{array}{c}\text { Anova test. } \\
\mathrm{df}=3 \\
\mathrm{p}=0.64 \text { (NS) }\end{array}$} \\
\hline & Primary & 10 & $255.79 \pm 236.29$ & \\
\hline & Secondary & 6 & $160.56 \pm 61.71$ & \\
\hline & University & 4 & $274 \pm 143.12$ & \\
\hline
\end{tabular}

Table 6. Comparison of salary status as regards consumer groups determined by the tools.

\begin{tabular}{|c|c|c|c|c|}
\hline & & \multicolumn{2}{|c|}{ Employee } & \multirow{2}{*}{$\mathrm{p}=$} \\
\hline & & YES & NO & \\
\hline \multirow[b]{2}{*}{ WHO Group } & WHO (+) & 10 & 21 & \multirow[b]{2}{*}{0.058 (NS) } \\
\hline & WHO (-) & 71 & 289 & \\
\hline \multirow[b]{2}{*}{ AUDIT Group } & AUDIT (+) & 13 & 28 & \multirow[b]{2}{*}{0.040} \\
\hline & AUDIT (-) & 68 & 282 & \\
\hline \multirow{2}{*}{ DETA Group } & DETA (+) & 14 & 18 & \multirow{2}{*}{0.001} \\
\hline & DETA $(-)$ & 67 & 292 & \\
\hline
\end{tabular}


However, our results make it possible for us to address the issue of sociodemographic factors associated with excessive alcohol consumption and could inform strategies for information and education of people for a change in behavior.

Among all the sociodemographic factors identified in our study, a statistically significant link has been established between alcohol and male gender, level of education and religion. Only the male factor is commonly reported by all authors [9] [10] [11] [12] [13]. Excessive drinkers are 2 - 5 times more common in men than in women. In our Burkinabe context, this could be explained by a higher taste for risk in men in addition of the social lifestyle, financial means and cult values of our people.

Overall, the average alcohol consumption in grams per week increased significantly with the education level. The more the patients were educated, the more alcohol they tend to drink. This finding is also reported by some authors [12] [13] [14]. But in our study, this increased consumption, however, remained within acceptable proportions. The proportional increase in consumption with the level of education is only found in the category of moderate drinkers. In the category of heavy users, distribution by level of study is homogeneous. This suggests that with education, patients succeed in using reasonably alcohol; or their answers to questionnaires do not match the reality. This phenomenon is not unusual, Rumpf et al. reported it already in 1997 [15].

Alcohol consumers are more found in other religions than Islam. It is indeed recognized that one of the most disclosed precepts of Islam is the ban of alcohol. It is assumed that Burkinabe society (Muslim in majority) still believes in God and respects these religious precepts. The literature is poor in study where mention is made of the religious characteristics of the patients studied. We can name TM. Ranzoni et al. who reported that in Brazil, Evangelical patients (Protestants) consumed less alcohol than other patients whose religion is unspecified [14].

The monthly income in the form of salary seems to favor excessive alcohol consumption. The statistical relationship is significant for consumer groups determined by questionnaires. The wages in our context do not reflect the real level of an individual's life but could provide a form of guarantee for expenditure planning.

Other demographic factors that include age, occupation, marital status are quite differently related to excessive alcohol consumption. In our study, this consumption was not linked to the same age even though it is commonly recognized and accepted that excessive consumption is more common among the youth [2] [3] [4] [16]. We do not see any link between heavy drinking and marital status and occupation. The literature provides many discordant studies on these factors [13] [17] [18] [19].

\section{Conclusion}

From sociodemographic factors, a link has been established between alcohol and male gender, level of education and religion in a population of hospitalized pa- 
tients. These data should first of all be supported by a survey on the general population and alcoholism. This validation would endorse a targeted communication strategy on these factors for morbidity reduction due to excessive alcohol consumption.

\section{References}

[1] Klotz, F., Guisset, M. and Laroche, R. (1992) Alcool et Pathologie en Afrique Noire. Médecine d'Afrique Noire, 39, 202-203.

[2] Adewuya, A.O. (2005) Validation of the Alcohol Use Disorders Identification Test (AUDIT) as a Screening Tool for Alcohol-Related Problems among Nigerian University Students. Alcohol and Alcoholism, 40, 575-577. https://doi.org/10.1093/alcalc/agh197

[3] Mabiala-Babela, J.R., Mahoungou-Guimbi, K.C., Massamba, A. and Senga, P. (2005) Consommation de l'alcool chez l'adolescent à Brazzaville (Congo). Cahiers Santé, $15,153-160$.

[4] Dagnan, N.S., Zengbé-Acray, P., Ahoussou, E.M.K., et al. (2014) Consommation d'alcool en milieu urbain chez les élèves du secondaire en Côte d'Ivoire. Santé Publique, 26, 107-114.

[5] La documentation française (2002) Usage de substances psychoactives. Identification des usages à risque, Outils de repérage, Conduite à tenir. Rapport au Directeur Général de la santé, Paris.

[6] Paille, F. (2002) Evaluation Pratique de la Consommation d'alcool Classifications et définitions des Conduites d'alcoolisation. Gastroentérologie Clinique et Biologique, 26, B141-B148.

[7] Saunders, J.B., Aasland, O.G., Babor, T.F., et al. (1993) Development of the Alcohol Use Disorders Identification Test (AUDIT): WHO Collaborative Project on Early Detection of Persons with Harmful Alcohol Consumption-II. Addiction, 88, 791804. https://doi.org/10.1111/j.1360-0443.1993.tb02093.x

[8] Ewing, J.A. (1984) Detecting Alcoholism: The CAGE Questionnaire. Journal of the American Medical Association, 252, 1905-1907. https://doi.org/10.1001/jama.1984.03350140051025

[9] Gerke, P., Hapke, U., Rumpf, H.J. and John, U. (1997) Alcohol-Related Diseases in General Hospital Patients. Alcohol and Alcoholism, 32, 179-184. https://doi.org/10.1093/oxfordjournals.alcalc.a008252

[10] Bradley, K.A., Bush, K.R., McDonell, M.B., et al. (1998) For Ambulatory Care Quality Improvement Project (Acquip). Screening for Problem Drinking: Comparison of CAGE and AUDIT. Journal of General Internal Medicine, 13, 379-388. https://doi.org/10.1046/j.1525-1497.1998.00118.x

[11] Fiellin, D.A., Reid, M.C. and O'connor, P.G. (2000) Screening for Alcohol Problems in Primary Care: A Systematic Review. Archives of Internal Medicine, 160, 19771989. https://doi.org/10.1001/archinte.160.13.1977

[12] Bataille, V., Ruidavets, J.B., Arveiler, D., et al. (2003) Joint Use of Clinical Parameters, Biological Markers and Cage Questionnaire for the Identification of Heavy Drinkers in a Large Population-Based Sample. Alcohol \& Alcoholism, 38, 121-127. https://doi.org/10.1093/alcalc/agg051

[13] Agabio, R., Nioi, M., Serra, C., Valle, P. and Gessa, G.L. (2006) Alcohol Use Disorders in Primary Care Patients in Cagliari, Italy. Alcohol \& Alcoholism, 41, 341-344. https://doi.org/10.1093/alcalc/agl010 
[14] Ronzani, T.M., Amato, T.C., Silveira, P.S., et al. (2007) Alcohol Use Pattern Assessment and Its Relation with Social-Demographic Variables among Patients of Primary Health Care (PHC) Poster Session Pb3: Epidemiology, Phenotyping, Comorbidity and Alcoholism. Alcohol and Alcoholism, 42, i62-i65. https://doi.org/10.1093/alcalc/agm132

[15] Rumpf, H.F., Hapke, U., Hill, A. and John, U. (1997) Development of a Screening Questionnaire for the General Hospital and General Practices. Alcoholism: Clinical and Experimental Research, 21, 894-898. https://doi.org/10.1111/j.1530-0277.1997.tb03854.x

[16] Mundle, G., Ackermann, K., Munkes, J., Steinle, D. and Mann, K. (1999) Influence of Age, Alcohol Consumption and Abstinence on the Sensitivity of Carbohydrate-Deficient Transferrin, Gamma-Glutamyltransferase and Mean Corpuscular Volume. Alcohol and Alcoholism, 34, 760-766. https://doi.org/10.1093/alcalc/34.5.760

[17] Varvasovszky, Z. and Mckee, M. (2000) Problem Drinking among Hospitalized Patients in Hungary. Alcohol and Alcoholism, 35, 574-579. https://doi.org/10.1093/alcalc/35.6.574

[18] Siegfried, N., Parry, C.D.H., Morojele, N.K. and Wason, D. (2001) Profile of Drinking Behaviour and Comparison of Self-Report with the CAGE Questionnaire and Carbohydrate-Deficient Transferrin in a Rural Lesotho Community. Alcohol and Alcoholism, 36, 243-248. https://doi.org/10.1093/alcalc/36.3.243

[19] Wu, S.I., Huang, H.C., Liu, S.I., et al. (2008) Validation and Comparison of Alcohol-Screening Instruments for Identifying Hazardous Drinking in Hospitalized Patients in Taiwan. Alcohol and Alcoholism, 43, 577-582. https://doi.org/10.1093/alcalc/agn036

Submit or recommend next manuscript to SCIRP and we will provide best service for you:

Accepting pre-submission inquiries through Email, Facebook, LinkedIn, Twitter, etc. A wide selection of journals (inclusive of 9 subjects, more than 200 journals)

Providing 24-hour high-quality service

User-friendly online submission system

Fair and swift peer-review system

Efficient typesetting and proofreading procedure

Display of the result of downloads and visits, as well as the number of cited articles

Maximum dissemination of your research work

Submit your manuscript at: http://papersubmission.scirp.org/

Or contact ojgas@scirp.org 